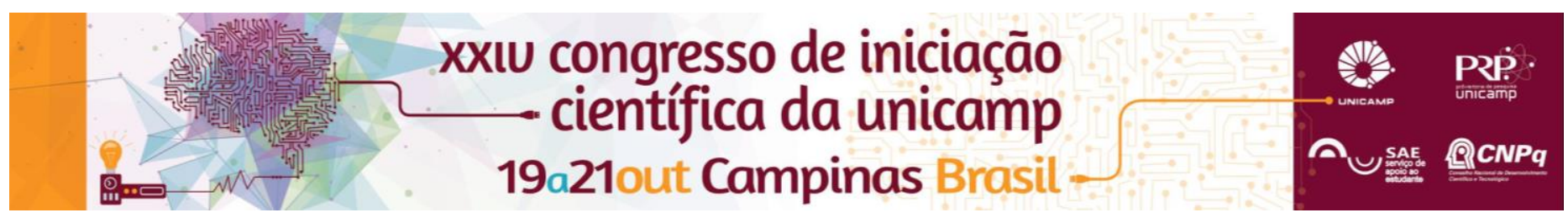

\title{
Receptores PPAR gama modulam a hipoalgesia induzida pelo exercício crônico
}

\author{
Beatriz Botasso Gomes, Graciana de Azambuja, Leonardo Henrique Dalcheco Messias, Fúlvia de Barros \\ Manchado Gobatto, Maria Cláudia G. Oliveira Fusaro
}

\section{Resumo}

Os receptores PPARy (Peroxisome proliferators-activated receptor gamma) desempenham um papel regulador importante na homeostase energética e no metabolismo. Estudos recentes apontam os receptores PPARy como alvos promissores para o tratamento de processos dolorosos, uma vez que os agonistas de receptores PPARy suprimem a dor inflamatória. O exercício é um tratamento não farmacológico eficaz para dores musculares e sabe-se que ele é capaz de aumentar a expressão de receptores PPARy no músculo esquelético. Nesse sentido, o objetivo do estudo foi avaliar se a hipoalgesia induzida pelo exercício é modulada pela ativação de receptores PPARY. Os resultados demonstraram que animais submetidos à natação crônica apresentaram hipoalgesia, e que esse processo foi modulado pela ativação de receptores PPARY.

\section{Palavras-chave:}

Dor muscular, natação, receptores PPARY

\section{Introdução}

As dores musculares agudas e crônicas representam um importante problema de saúde mundial. Sabe-se que o exercício é um tratamento não farmacológico eficaz para dores musculares, entretanto, os mecanismos envolvidos nesse processo não estão totalmente elucidados. Considerando-se que o exercício aumenta a expressão de receptores PPARy no músculo e que eles estão envolvidos com a modulação da dor, o objetivo do presente estudo foi avaliar se a hipoalgesia induzida pelo exercício é modulada pela ativação de receptores PPARY.

\section{Resultados e Discussão}

Foram utilizados Ratos Wistar machos provenientes do CEMIB-UNICAMP. Os procedimentos experimentais foram aprovados pelo CEUA, número 3869-1.

Os animais foram submetidos a dois protocolos de treinamento: um clássico, com cargas a $4 \%$ do peso corporal e outro individualizado, com cargas a $80 \%$ da MFEL (Máxima Fase Estável do Lactato). Ambos com duração de 40 minutos, 5 dias por semana num período de 10 semanas. Após 5 semanas de exercício, as cargas foram reajustadas.

O comportamento doloroso foi induzido através da injeção de carragenina $(100 \mu \mathrm{g})$ no músculo gastrocnêmio após as 10 semanas de treinamento e avaliado, três horas depois, através do analgesímetro de pressão, Randall Selitto. O envolvimento dos receptores PPARY foi testado através do pré-tratamento local com GW9662, um antagonista seletivo dos receptores PPARy.
Figura 1. Receptores PPARy modulam a hipoalgesia induzida pelo exercício
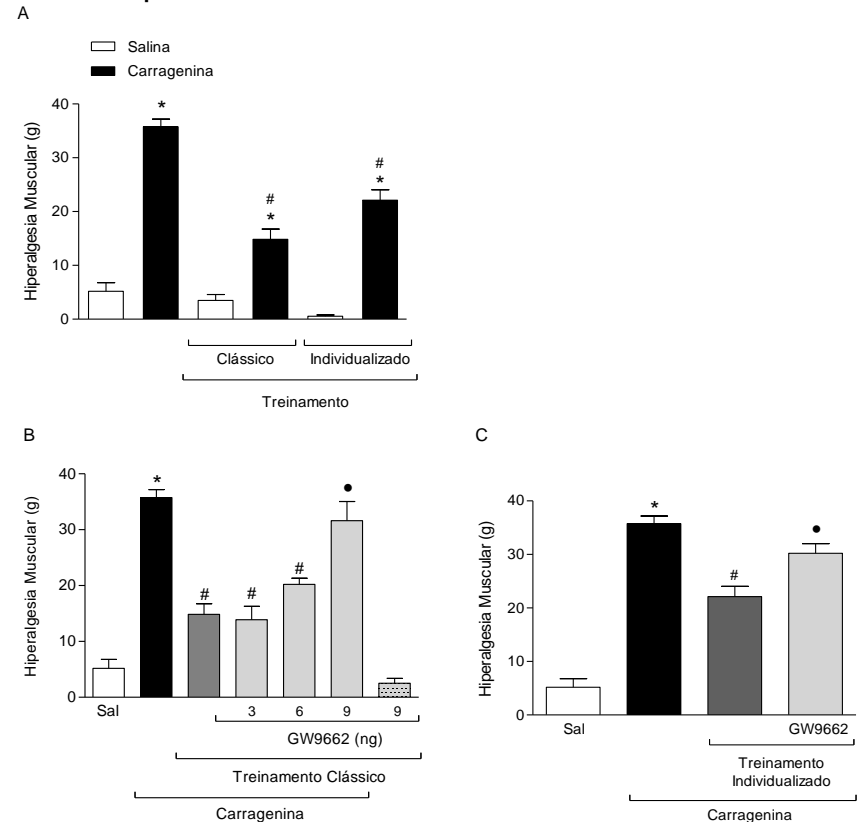

Fig. 1. O exercício crônico, clássico e individualizado, induziram hipoalgesia muscular (A). O pré-tratamento com GW9662 (9ng) reverteu a hipoalgesia induzida pelo treinamento clássico (B) e individualizado (C). Sozinho, GW9662 não alterou o limiar nociceptivo (B). Os símbolos "*” indicam respostas maiores do que os grupos salina ( $n=4$, ANOVA, pós teste de Tukey). Os símbolos "\#" indicam respostas menores do que o grupo de carragenina sem treinamento ( $n=4$, ANOVA, pós teste de Tukey). Os símbolos "•" indicam respostas maiores do que o grupo de carragenina com treinamento $(n=4$, ANOVA, pós teste de Tukey).

\section{Conclusões}

Os resultados confirmam que o exercício crônico induz hipoalgesia. Além disso, demonstram que esse processo é modulado pela ativação de receptores PPARy. Portanto, a ativação dos receptores PPARy por mecanismos indiretos, como exercícios crônicos, poderia ser um alvo para controlar a dor crônica musculoesquelética.

\section{Agradecimentos}

Fundação de Amparo à Pesquisa do Estado de São Paulo - FAPESP (2015/20738-0); PIBIC/CNPq. 